\title{
UPAYA MENINGKATKAN HASIL BELAJAR ILMU PENGETAHUAN ALAM (IPA) DENGAN MENERAPKAN MODEL INQUIRY TRAINING BERBANTUAN MEDIA AUDIO VISUAL PADA KELAS IV SDN 1 NARAHAN TAHUN PELAJARAN 2016/2017
}

\author{
Oleh \\ Sri Kartika Hayati ${ }^{1}$, Diplan ${ }^{2}$
}

\begin{abstract}
ABSTRAK
Penelitian ini bertujuan untuk: (1) Mendeskripsikan aktivitas peserta didik dalam pembelajaran Ilmu Pengetahuan Alam (IPA) dengan menerapkan model Inquiry Training berbantuan media Audiovisual pada peserta didik kelas IV SDN 1 Narahan Tahun Pelajaran 2016/2017, (2) Meningkatkan hasil belajar Ilmu Pengetahuan Alam (IPA) peserta didik kelas IV SDN 1 Narahan dengan menerapkan model pembelajaran Inquiry Training berbantuan media Audiovisual. Jenis Penelitian ini menggunakan Penelitian Tindakan Kelas (PTK).Subjek dalam penelitian ini adalah seluruh peserta didik kelas IV SDN 1 Narahan, yang berjumlah 14 orang peserta didik dengan komposisi laki-laki 10 orang dan perempuan 4 orang. Teknik pengumpulan data berdasarkan pada kualitatif dan kuantitatif dalam penelitian ini menggunakan tes tertulis pada akhir proses Pembelajaran. Hasil penelitian menunjukkan bahwa dengan menerapkan model pembelajaran Inquiry Training berbantuan media Audiovisual (1)Aktivitas peserta didik dalam pembelajaran Ilmu Pengetahuan Alam (IPA) menerapkan model pembelajaran Inquiry Training berbantuan media Audiovisual materi Perubahan Lingkungan Fisik Bumi pada peserta didik kelas IV SDN 1 Narahan Tahun Pelajaran 2016/2017 menjadi baik. Hal ini dapat dilihat dari penilaian observasi oleh pengamat yaitu pada siklus I aktivitas peserta didik mendapatkan skor rata-rata 3,10 dengan kategori baik sedangkan pada siklus II aktivitas peserta didik mengalami peningkatan dengan skor rata-rata 3,80 dan kategori baik. (2)Ada peningkatan hasil belajar Ilmu Pengetahuan Alam (IPA) dengan dengan menerapkan model pembelajaran Inquiry Training berbantuan media Audiovisual pada peserta didik kelas IV SDN 1 Narahan Tahun Pelajaran 2016/2017. Hal ini dapat diketahui pada Pre Test dengan nilai rata-rata yaitu 50 dengan presentase ketuntasan klasikal 14,28\%, mengalami peningkatan pada siklus I yakni dengan nilai rata-rata 65 dengan presentase ketuntasan klasikal 64,28\%. dan hasil yang dicapai peserta didik pada siklus II untuk nilai rata-rata kelas lebih meningkat dari siklus sebelumnya yaitu dengan nilai rata-rata 85 dengan presentase ketuntasan klasikal $100 \%$.
\end{abstract}

(C) Universitas Muhammadiyah Palangkaraya

Kata Kunci: Hasil Belajar IPA, Model Inquiry Training berbantuan Media Audio visual 


\section{PENDAHULUAN}

Pendidikan adalah sebagai suatu usaha sadar dan terencana untuk mewujudkan suasana belajar dan proses pembelajaran untuk peserta didik secara aktif mengembangkan potensi dirinya. Pendidikan di sekolah dasar adalah sebagai proses pengembangan kemampuan yang paling mendasar bagi setiap peserta didik dimana setiap peserta didik belajar secara aktif karena adanya suasana yang memberikan kemudahan bagi perkembangan dirinya secara optimal. Undang-Undang Republik Indonesia Nomor 20 tahun 2003 tentang Sistem Pendidikan Nasional Bab I pasal I menjelaskan bahwa :

Pendidikan adalah usaha sadar dan terencana untuk mewujudkan suasana belajar dan proses pembelajaran agar peserta didik secara aktif mengembangkan potensi dirinya untuk memiliki kekuatan spiritual keagamaan, pengendalian diri, kepribadian, kecerdasan akhlak mulia, serta keterampilan yang diperlukan dirinya, masyarakat, bangsa dan negara yang diwujudkan dalam berbagai kegiatan pendidikan baik formal, informal, maupun nonformal. Kegiatan pendidikan jalur formal terdiri atas pendidikan dasar, pendidikan menengah, dan pendidikan tinggi.

Guru sebagai kunci keberhasilan dalam proses pembelajaran harus mampu menyajikan proses pembelajaran dengan baik di kelas. Model pembelajaran yang digunakan oleh guru harus sesuai dengan materi yang sedang diajarkan, karena tidak semua model, metode, maupun media pembelajaran dapat digunakan untuk semua materi. Pemilihan model pembelajaran yang tepat serta media penunjang kegiatan pembelajaran akan berpengaruh terhadap hasil pembelajaran yang akan dicapai.

Ilmu Pengetahuan Alam (IPA) merupakan salah satu mata pelajaran yang diberikan kepada peserta didik pada jenjang pendidikan dasar dan menengah. Pembelajaran kooperatif merupakan salah satu langkah yang dapat ditempuh untuk memperbaiki sekaligus meningkatkan hasil belajar peserta didik khususnya pada mata pelajaran Ilmu Pengetahuan Alam (IPA).

Pembelajaran kooperatif adalah suatu pembelajaran kelompok yang dapat meningkatkan prestasi belajar peserta didik dan sekaligus dapat meningkatkan kemampuan hubungan sosial, menumbuhkan sikap menerima kekurangan diri dan orang lain,dapat meningkatkan harga diri, merealisasikan kebutuhan peserta didik dalam belajar berpikir, memecahkan masalah, dan mengintegrasikan pengetahuan dengan keterampilan.

Berdasarkan hasil observasi yang dilakukan di kelas IV aktivitas dan hasil belajar peserta didik di kelas IV SDN 1 Narahan masih rendah dibawah kriteria ketuntasan minimal (KKM) yang ditetapkan yaitu 65 untuk pelajaran Ilmu Pengetahuan Alam (IPA). Dari 14 peserta didik, hanya $4=28,57 \%$ orang yang memperoleh nilai memenuhi KKM dan sisanya $10=71,43 \%$ peserta didik memperoleh nilai rata-rata 50,00 di bawah KKM. 
Model Inquiry Training merupakan tipe pembelajaran kooperatif dan salah satu alternatif yang dapat diterapkan untuk meningkatkan aktivitas sekaligus hasil belajar peserta didik khususnya pada mata pelajaran Ilmu Pengetahuan Alam (IPA). Pengetahuan dan keterampilan yang diperoleh peserta didik bukan hasil menghapal tetapi hasil menemukan sendiri berbantuan pengamatan, percobaan (eksperimen) dan eksplorasi.

$$
\text { Melalui model Inquiry }
$$

Training disertai penggunaan media Audiovisual dapat membuat pembelajaran lebih menyenangkan,

\section{METODE PENELITIAN}

Penelitian ini menggunakan Penelitian Tindakan Kelas (PTK). Penelitian tindakan kelas atau PTK (classroom Action Research) memiliki peranan yang sangat penting dan strategis untuk meningkatkakn mutu pembelajaran apabila diimplementasikan dengan baik dan benar. Diimplementasikan dengan baik, artinya pihak yang terlibat dalam PTK mencoba dengan sadar mengembangkan kemampuan dalam mendektesi dan memecahkan masalah-masalah yang terjadi dalam pembelajaran dikelas melalui tindakan bermakna yang diperhitungkan dapat memecahkan masalah atau memperbaki situasi dan kemudian secara cermat mengamati pelaksanaannya untuk mengukur tingkat kebehasilannya. Di implementasi dengan benar, artinya sesuai dengan kaidah-kaidah PTK.

Menurut Kemmis dan

Mc.taggart, (Kunandar, 2013:42) menarik, kreatif, dan inovatif bagi peserta didik sekolah dasar. Model pembelajaran ini menekankan proses berpikir secara kritis dan analitis untuk mencari dan menemukan sendiri jawaban dari suatu masalah yang dipertanyakan serta meningkatkan keaktifan peserta didik dalam mencari dan menentukan masalah yang dihadapi, karena di dalamnya peserta didik diajak untuk berinteraksi peserta didik dengan guru dan peserta didik dengan peserta didik, bertukar pikiran mengenai materi yang sedang di pelajari, sehingga mereka menjadi aktif dan tidak bosan dalam pembelajaran. penelitian tindakan adalah suatu bentuk self-inquiry kolektif yang dilakukan oleh para partisipan di dalam situasi sosial untuk meningkatkan rasionalitas dan keadilan dari praktik sosial atau pendidkan yang mmereka lakukan, serta mempertinggi pemahaman mereka terhadap prktik dan situasi dimana praktik itu dilaksanakan.

Data yang dikumpulkan dari setiap siklus akan dianalisis menggunakan metode Mixed Methods atau metode kombinasi antara kualitatif dan kuantitatif. Creswell (Sugiyono, 2013:224) menyatakan bahwa "metode penelitian kombinasi (Mixed Methods) akan berguna bila metode kualitatif atau metode kuantitatif secara sendiri-sendiri tidak cukup akurat digunakan untuk memahami permasalahan penelitian atau dengan menggunakan metode kualitatif dan kuantitatif secara kombinasi akan dapat memperoleh pemahaman paling baik, sehingga diperoleh data yang lebih komprehensif, valid, reliable, dan obyektif. 
Analisis kualitatif yaitu untuk menganalisis data yang menunjukkan aktivitas peserta didik yang terjadi selama proses pembelajaran berlangsung yang diperoleh dari lembar observasi aktivitas peserta didik.

\section{HASIL DAN PEMBAHASAN}

\section{Deskripsi Data Pra Tindakan}

\section{(Data Awal)}

Data pra tindakan terdiri atas data hasil tes awal (pre test). Data awal ini bertujuan untuk mengetahui tingkat kemampuan awal peserta didik terhadap materi yang akan dijadikan topik pembelajaran sebelum penelitian tindakan kelas berlangsung. Adapun pra tindakan dilaksanakan pada hari Selasa, 11 April 2017 pada pukul 07.00 - 07.30 Wib. Bentuk tes yang dilakukan dengan memberikan soal sebanyak 10 soal isian dari pembelajaran Ilmu Pengetahuan Alam (IPA) sebelum belajar materi tentang perubahan lingkungan fisik bumi.

Dengan menerapkan model Inquiry Training berbantuan media Audiovisual. Hasil belajar yang diperoleh peserta didik pada pra tindakan ini dari 14 peserta didik yang memperoleh nilai 65 ke atas hanya 2 orang (14,28\%), sedangkan yang memperoleh nilai di bawah 65 sebanyak 12 orang ( $85,72 \%$ ).

\section{Siklus I}

Pada siklus I ada peningkatan yang dari pra tindakan, dengan menerapkan model Inquiry Training berbantuan media
Analisis kuantitatif digunakan untuk melihat ada atau tidaknya peningkatan hasil belajar peserta didik dengan menerapkan model pembelajaran Inquiry Training berbantuan media Audiovisual.

Audiovisual dengan nlai rata-rata 65 dan presentase ketuntasan klasikal $64,28 \%$ dan belum mencapai $85 \%$. Aktivitas guru 3,32 dan peserta didik 3,10. Berdasarkan hasil Pelaksanaan siklus II ini dimaksud untuk memperbaiki penelitian pada siklus I yang dipandang belum berhasil oleh penliti.

\section{Siklus II}

Aktivitas pada guru pada siklus I memperoleh nilai rata-rata 3,32 sedangkan pada siklus II ada peningkatan menjadi baik dengan penilaian rata-rata pengamat sebesar 3,79 dan aktivitas peserta didik pada siklus I nilai rata-rata 3,10 sedangkan pada siklus II meningkat menjadi 3,80. Pada pra tindakan belum memuaskan karena mendapatkan nilai rata-rata 50 dan presentase ketuntasan belajar 14,28\% , pada siklus I presentase ketuntasan belajar peserta didik mengalami peningkatan namun belum mencapai indikator ketuntasan $85 \%$ yang hanya mendapat $64,28 \%$ dan mendapat nilai rata-rata 65 . Pada siklus II nilai peserta didik mengalami peningkatan dengan penilaian rata-rata 85 dengan kreteria mencapai $100 \%$. Penilaian menganggap pada sikllus II ini sudah berhasil karena telah mencapai nilai KKM dan telah berhasil mencapai nilai ketuntasan klasikal 


\section{SIMPULAN}

Berdasarkan hasil penelitian yang telah dibahas maka dapat disimpulkan :

1. Aktivitas peserta didik menjadi baik dalam pembelajaran Ilmu Pengetahuan Alam (IPA) dengan menerapkan model Inquiry Training berbantuan media Audiovisual pada peserta didik kelas IV SDN 1 Narahan Tahun Pelajaran 2016/2017. Hal tersebut terlihat pada aktivitas peserta didik pada siklus I dengan skor rata-rata 3,10 dan pada siklus II ada peningkatan skor rata-rata 3,80 dengan kategori baik.

DAFTAR PUSTAKA

Kunandar. (2013). Langkah Mudah Penelitian Tindakan Kelas. Jakarta: Putra Kharisma Putra
2. Ada peningkatan hasil belajar Ilmu Pengetahuan Alam (IPA) dengan menerapkan model Inquiry Training berbantuan media Audiovisual pada peserta didik kelas IV SDN 1 Narahan tahun pelajaran 2016/2017. Pada pre test peserta didik mendapatkan rata-rata 50 dengan presentase ketuntasan klasikal $14,28 \%$. Pada siklus I diperoleh hasil rata-rata 65 dengan persentasae ketuntasan klasikal 64,28\% dan pada siklus II diperoleh hasil rata-rata 85 dengan presentase ketuntasan klasikal 100\%.

Urama Offset.

Sugiyono. (2010). Perencanaan Pembelajaran. Jakarta: Trans Mandiri Abadi. 